\title{
A DESCRIPTION OF THE \\ ECTAL MANDIBULAR GLAND IN THE PAPER WASP \\ POLISTES FUSCATUS (HYMENOPTERA: VESPIDAE)*
}

\author{
By H. A. Downing and R. L. Jeanne \\ Department of Entomology \\ University of Wisconsin \\ Madison, Wisconsin 53706
}

While the ectal mandibular gland is a source of queen substance in both honey bees and bumble bees (Butler and Simpson, 1958; van Honk et al., 1980), little is known about this gland in the vespids. In Vespula and Polistes spp. the mandibular gland consists of 50 to 70 ducted gland cells opening into a reservoir which in turn is said to empty into the oral cavity at the base of the mandible (Hermann et al., 1971; Spradbery, 1973; Landolt and Akre, 1979). Nedel (1960), however, found that the mandibular gland of $V$. germanica $(F$.) opens anterior to the anterior condyle and thus to the front of the face. He describes a small brush of mechanoreceptors on the mandible.

Because the mandibular gland is so much smaller in wasps than in bees, Spradbery (1973) suggested that it probably has no social function in wasps. However, the fact that this gland is the largest of the cephalic exocrine glands in wasps and the discrepancies in the literature concerning the locus of the gland opening caution against such a conclusion. The purpose of the present study is to investigate the morphology of the ectal mandibular gland in Polistes fuscatus with reference to possible gland function.

\section{MethodS}

Micrographs of the exterior opening of the ectal mandibular gland were taken using the JELCO JSM-U3 scanning electron microscope. Quarter sections of female wasp heads containing the ectal mandibular gland were fixed in Kahle's solution and embedded in Spurr Low-Viscosity embedding media (Polysciences) following the methods of Spurr (1969). Sections $2 \mu$ thick were cut with a glass

*Manuscript received by the editor September 23, 1982. 
knife on a Porter-Blum-Microtome MT-1 (Sorvall ${ }^{\circledR}$ ), stained using Mallory's Azure II-Methylene Blue (Richardson et al., 1960), and examined using a light microscope.

\section{Results AND Discussion}

The ectal mandibular gland in P. fuscatus females is similar to the ectal mandibular gland Nedel (1960) described for V. germanica. The gland reservoir, which lies appressed to the gena, opens at the base of the mandible via a long, flattened, sclerotized duct. Gland cells can be seen on the outer surface of the reservoir (Figure 1a). The sclerotized duct of the reservoir opens on to the mandibular surface just above a brush of bristles (Figure $1 \mathrm{~b}$ ). The bristles may be mechanoreceptors and may also serve to increase the surface area for evaporation of the glandular secretion. A scallop of cuticle extends ventrally from the gena, covering the brush when the mandible is closed. When the mandible is opened even slightly the brush is exposed on the front of the face (Figure 2).

The position of the ectal mandibular gland opening suggests a social rather than a physiological function. Because it does not open into the mouth, this gland is probably not a source of digestive enzymes or nest construction material. P. fuscatus colonies are initiated by one or more overwintered female gynes, which work together to raise the brood. Aggressive interactions result in the formation of a dominance hierarchy in which the most dominant individual is the egg-layer for the colony (Pardi, 1948). The dominant female must maintain a certain level of aggression in order to retain her dominant status, but her elevated rank is communicated by chemical cues originating in the head (Downing, 1982). Dominant wasps frequently chew on the head and thorax of their subordinates, and when threatening other females will lunge toward them with open mandibles. The ectal mandibular gland opening is exposed at these times, suggesting that it may be the source of chemical signals important for the communication of status during aggressive interactions.

\section{ACKNOWLEDGEMENTS}

We would like to thank D. Post and B. J. Harrington for providing useful criticisms on early drafts of this manuscript. The research 

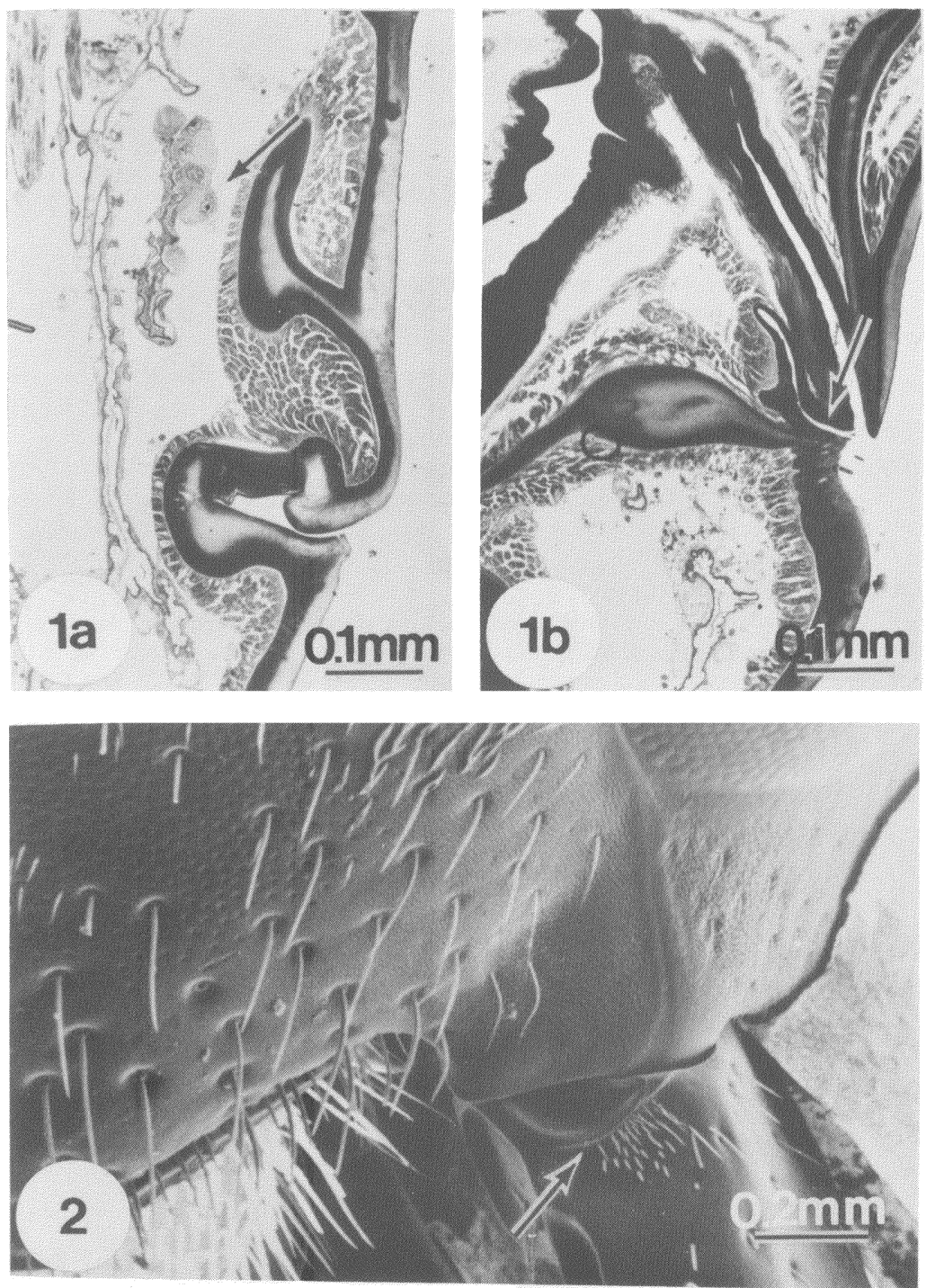

Figs. 1-2. Fig. 1. Ectal mandibular gland histology. Sagittal sections through a) reservoir (arrow points to gland cells at the top of reservoir) and b) reservoir duct, showing duct opening to the mandibular brush (arrow). Anterior is to the right. Fig. 2. Ectal mandibular gland opening, frontal view. SEM micrograph of the exposed mandibular brush, located just below the opening of the ectal mandibular gland (arrow). The mandible is in an open position. Clypeus is on the left, compound eye in the upper right. 
was supported by the College of Agricultural and Life Sciences, University of Wisconsin, Madison, and by National Science Foundation Grant BNS-77-04081.

\section{Literature Cited}

\section{Butler, C. G. AND J. Simpson}

1958. The source of the queen substance of the honey bee (Apis mellifera L.). Proc. Roy. Entomol. Soc. Lond. A. 33:120-122.

DownING, H. A.

1982. Glandular differences and communication of rank among females in a dominance hierarchy of Polistes fuscatus (Hymenoptera: Vespidae). M.Sc. Thesis, Univ. Wisconsin, Madison.

Hermann, H. R., A. N. Hunt, and W. E. Buren.

1971. Mandibular gland and mandibular groove in Polistes annularis (L.) and Vespula maculata (L.) (Hymenoptera: Vespidae). Int. J. Ins. Morphol. Embryol. 1:43-49.

LANDolt, P. J. AND R. D. AKre.

1979. Occurrence and location of exocrine glands in some social Vespidae (Hymenoptera). Ann. Entomol. Soc. Am. 72:141-148.

Nedel, J. O.

1960. Morphologie und Physiologie der Mandibeldrüse einiger Bienen Arten (Apidae). Z. Morphol. Ökol. Tiere, 49:139-183.

PARDI, L.

1948. Dominance order in Polistes wasps. Physiol. Zool. 21:1-13.

Richardson, K. C., L. JaretT, AND E. H. FinKe.

1960. Embedding in epoxy resins for ultrathin sectioning in electron microscopy. Stain Technol., 35:313-323.

SPRADBERY, J. P.

1973. Wasps. Seattle: University of Washington Press. 408 pp.

SPURR, A. R.

1969. A low viscosity epoxy resin embedding medium for electron microscopy.

J. Ultrastructure Res. 26:31-43.

Van Honk, C. G. J., H. H. W. Velthuis, P. F. Röseler, and M. E. Malotaux.

1980. The mandibular glands of Bombus terrestris queens as a source of queen pheromones. Entomol. Exp. Appl. 28:191-198. 



Submit your manuscripts at

http://www.hindawi.com
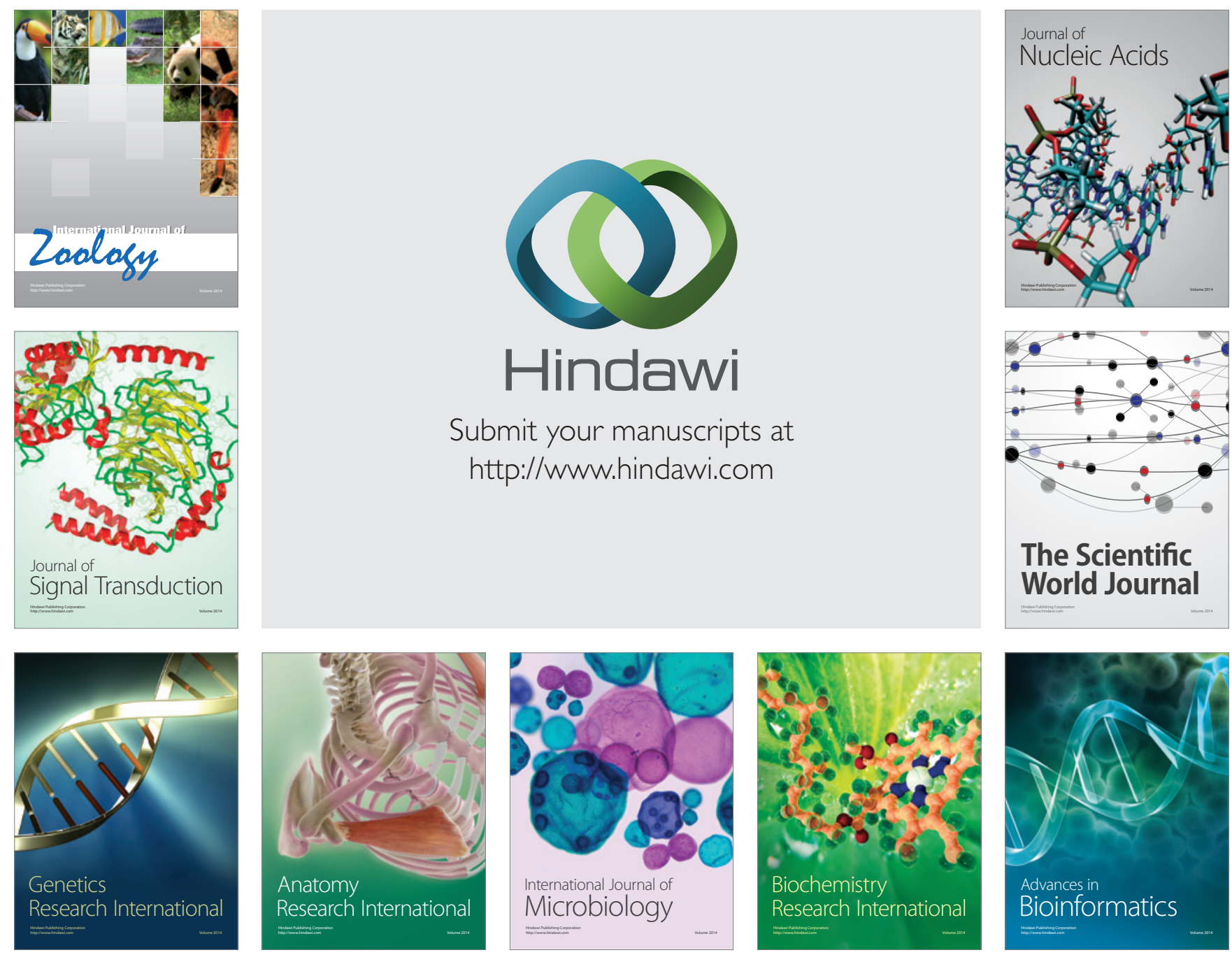

The Scientific World Journal
